\title{
ANÁLISE MACROSCÓPICA DO CÓRREGO ALMECEGAS MUNICÍPIO DE CORAÇÃO DE JESUS-MG
}

Dalvana Pereira Santos - dalvanasantos123@gmail.com

Faculdade de Ciência Exatas e Tecnológicas Santo Agostinho - FACET

Clayton Dion Mendes Oliveira - clayton.d.mendes@ gmail.com

Faculdade de Ciência Exatas e Tecnológicas Santo Agostinho - FACET

Franciele Alves Santos - francielealvessantos@ hotmail.com

Faculdade de Ciência Exatas e Tecnológicas Santo Agostinho - FACET

Keite Gonçalves Silva - keitesilva6@gmail.com

Faculdade de Ciência Exatas e Tecnológicas Santo Agostinho - FACET

Felipe Aquino Lima - felipea@fasa.edu.br

Faculdade de Ciência Exatas e Tecnológicas Santo Agostinho - FACET

Adailton Pereira Ferreira - adailtonefst@gmail.com 


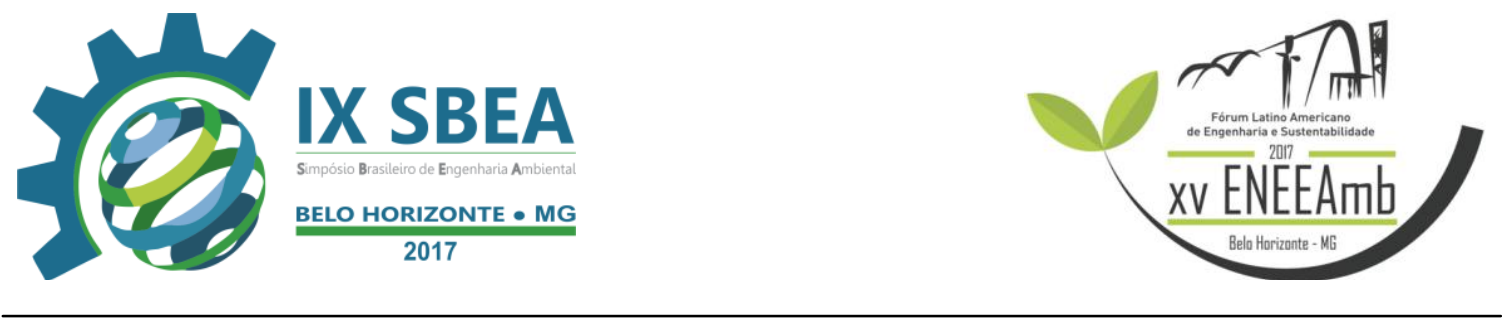

\section{RESUMO}

A água é de grande utilidade para o homem, destacando o uso como via de transporte, como fonte de energia e, principalmente, como um elemento econômico, pois é essencial para expansão da agropecuária. Por isso, é um recurso bastante utilizado. Em razão disso, apresenta sinais de degradação, o que indica alterações e quebra do equilíbrio natural. Este trabalho teve como objetivo avaliar o curso hídrico denominado Córrego Almécegas, localizado na zona rural do município de Coração de Jesus onde se objetivou avaliar parâmetros ambientais macroscópicos, além de identificar os principais problemas de degradação nos pontos coletados. Foi feita uma analise macroscópica de três pontos ao longo do curso hídrico, a nascente, meio do rio e a foz, observando-se treze parâmetros de qualidades das águas, proposta. Após a coleta de dados os parâmetros macroscópicos foram enquadrados em padrões para a quantificação. Realizou-se a somatória dos pontos obtidos. Posteriormente, foram distribuídos por uma tabela classificatória que indica o grau de preservação e a classe que cada ponto está enquadrado. Pode-se observar ao longo do curso hídrico pontos de degradação que possivelmente origina-se da ação antrópica.

Palavra Chave: água, degradação, ação antrópica, parâmetros, qualidades das águas.

\section{INTRODUÇÃO/OBJETIVO}

A disponibilidade de água limpa é potencialmente um dos grandes desafios a serem tratados pela sociedade contemporânea nos próximos anos. A atenção para os recursos hídricos merece prioridade, pois a água doce existe em pequena escala, perfazendo 2,5\% do total presente no planeta (GLEICK, 2000). Em termos médios, entre os países em desenvolvimento e os desenvolvidos, estima-se que o uso da água seja em torno de $69 \%$ na agricultura, $23 \%$ na indústria e $8 \%$ nas atividades domésticas. Nos moldes do desenvolvimento econômico atual, grande parte da água ainda é utilizada de forma irracional, favorecendo o desperdício e o manejo inadequado e não sustentável desse recurso. Este fato agrava-se ao passo que ocorre a distribuição heterogênea dos recursos hídricos, e como a comunidade global está difundida. Consequentemente, constata-se que a água não se encontra a disposição e com 


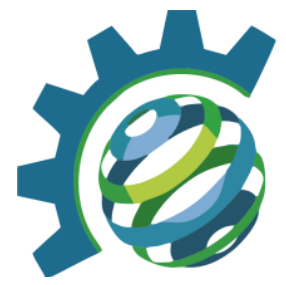

qualidade para atender a todas as necessidades humanas em grande parte das localidades.

De forma genérica, a poluição das águas decorre da adição de substâncias ou de formas de energia que, diretamente ou indiretamente, alteram as características físicas e químicas do corpo d'água de uma maneira tal, que prejudique a utilização das suas águas para usos benéficos. Torna-se importante ressaltar a existência dos seguintes tipos de fontes de poluição (Tucci, 1998): atmosféricas, pontuais, difusas e mistas. Cada uma das fontes de poluição citadas determina certo grau de poluição no corpo hídrico atingido, que é mensurado através de características físicas, químicas e biológicas das impurezas existentes, que, por sua vez, são identificadas por parâmetros de qualidade das águas (físicos e químicos). De uma maneira geral, as características físicas são analisadas sob o ponto de vista de sólidos (suspensos, coloidais e dissolvidos na água), gases e temperatura. As características químicas, nos aspectos de substâncias orgânicas inorgânicas. A água pode ter sua qualidade afetada pelas mais diversas atividades do homem, sejam elas domésticas, comerciais ou industriais. Cada uma dessas atividades gera poluentes característicos que têm uma determinada implicação na qualidade do corpo receptor.

Este trabalho teve como objetivo avaliar o curso hídrico denominado Córrego Almecegas da zona rural do município de Coração de Jesus de acordo como parâmetros macroscópicos e identificar os principais problemas de degradação nos pontos coletados.

\section{METODOLOGIA}

\section{1 Área de Estudo}

A área de estudo está localizada na região norte do estado de Minas Gerais, entre as coordenadas geográficas $16^{\circ} 26^{\prime} 00^{\prime} \mathrm{S}$ e $16^{\circ} 30^{\prime} 00^{\prime} \mathrm{S}$ de Latitude, e $44^{\circ} 19^{\prime} 00^{\prime \prime} \mathrm{W}$ e 44¹6’00’'W de Longitude (Figura 1). 

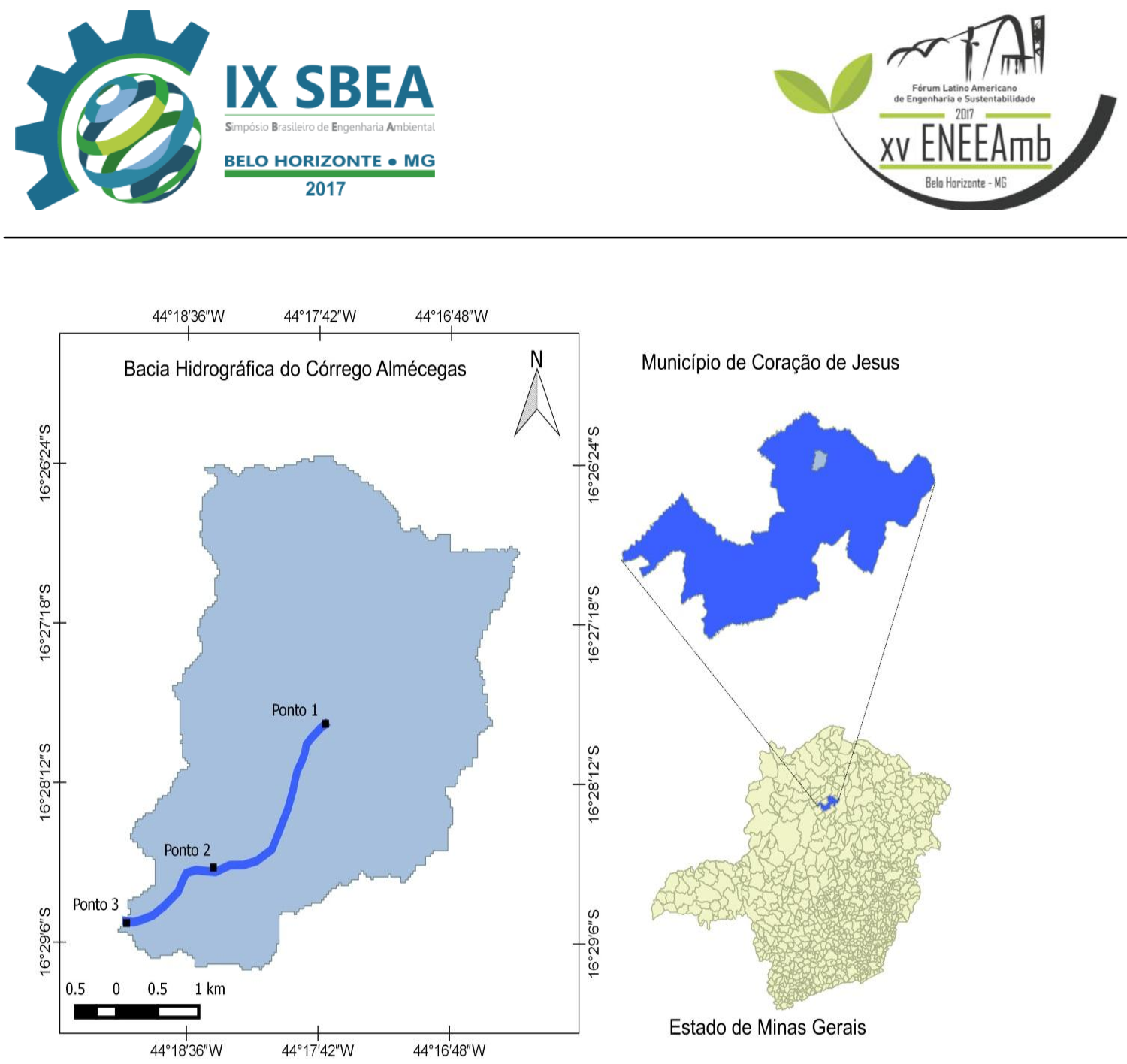

Municipio de Coração de Jesus

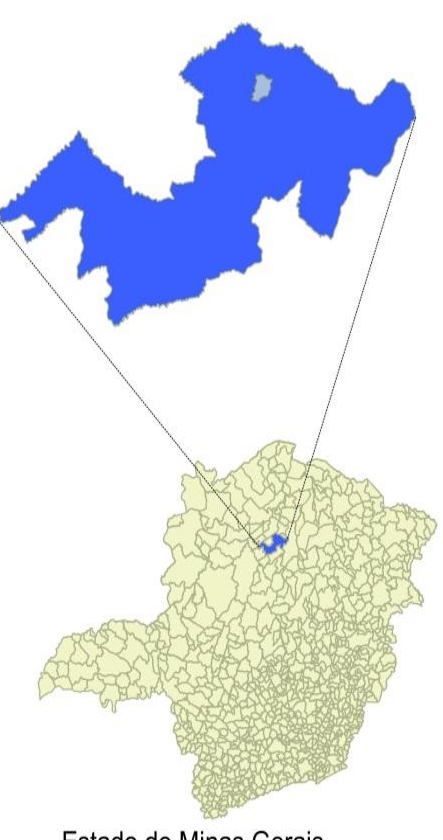

Estado de Minas Gerais

Figura 1. Localização geográfica do Córrego Almecegas Fonte: Próprio Autor

\subsection{Coletas de Dados}

$\mathrm{Na}$ análise dos pontos foram observados treze parâmetros para quantificação da analise macroscópica, seguindo metodologia proposta por Gomes et al., (2005) que são os seguintes:

I. Coloração aparente da água (deve-se de distinguir entre cor aparente e cor verdadeira. No valor de cor aparente pode ser incluída uma parcela devido a turbidez da agua. Quando esta é removida por centrifugação, obtém-se a cor verdadeira): com uso de recipiente transparente para coleta e verificação da cor.

II. Odor da água: com uso de recipiente para a coleta e verificação do odor.

III. Lixo no entorno: presença de lixo na região da nascente e caracterização dos mesmos.

IV. Materiais Flutuantes: presença de objetos na superfície da agua e caracterização dos mesmos.

V. Espumas e óleos: presença na superfície da água.

VI. Esgoto: presença de emissários e sua distância da nascente.

VII. Vegetação: caracterização da mesma á nascente e classificação quanto á preservação (Alto grau de degradação, Baixo Grau de degradação, Preservada).

VIII. Uso por animais: evidencia de uso por animais- presença, pegadas, fezes, tocas e esqueletos.

IX. Uso antrópico: evidencia da utilização na área por humanos- trilhas ao redor da área, presença de bombas de sucção e irrigação de hortas e plantações.

X. Proteção: existência de algum tipo de proteção ao redor da nascente, por barreiras naturais, ou por barreiras artificias e sua caracterização. 


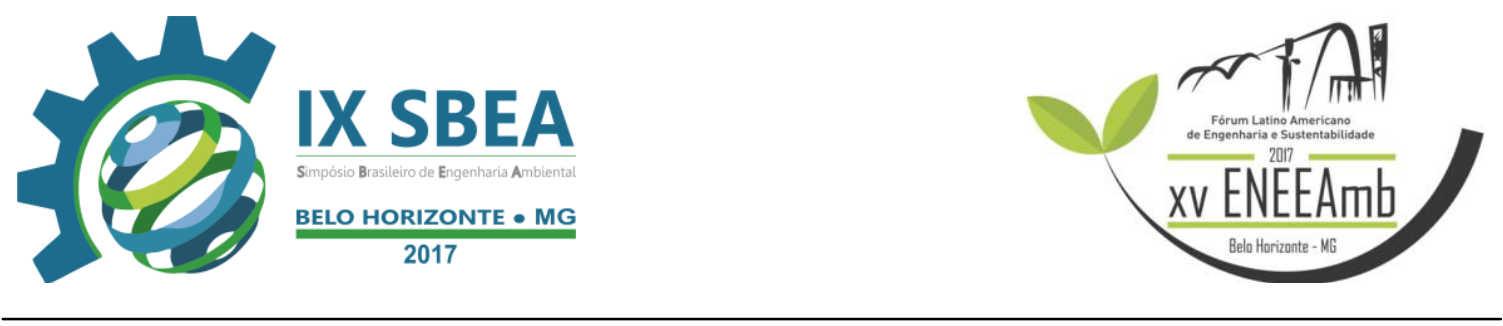

XI. Identificação: presença de placas ou similar indicando a existência da nascente no local ou informações educativas.

XII. Residências: quantificação aproximada de distância, em metros do rio até as residências, estabelecimentos comerciais ou indústrias mais próximas.

XIII. Tipo de área de inserção: se a nascente está localizada em área que visa a preservação local.

\subsection{Amostragem dos Parâmetros Macroscópicos}

Após a coleta de dados os parâmetros macroscópicos foram enquadrados em padrões para a quantificação. Realizou-se a somatória dos pontos obtidos. Posteriormente, foram distribuídos por uma tabela classificatória que indica o grau de preservação e a classe que cada ponto está enquadrado, Tabela 1.

Tabela 1. Quantificação das análises dos parâmetros macroscópicos.

\begin{tabular}{|c|c|c|c|}
\hline $\begin{array}{l}\text { Cor da água } \\
\text { Odor }\end{array}$ & $\begin{array}{l}\text { Escura } \\
\text { (1) Cheiro forte }\end{array}$ & $\begin{array}{l}\text { (2) Clara } \\
\text { (2) Cheiro Fraco }\end{array}$ & $\begin{array}{l}\text { (3) Transparente } \\
\text { (3) Sem Cheiro }\end{array}$ \\
\hline Lixo ao redor & (1) Muito & (2) Pouco & (3) Sem Lixo \\
\hline Materiais flutuantes & (1) Muito & (2) Pouco & Materiais \\
\hline Espumas & (1) Muita & (2) Pouca & $\begin{array}{l}\text { Flutuantes } \\
\text { (3) Sem espumas }\end{array}$ \\
\hline Óleos & (1) Muito & (2) Pouco & (3) Sem óleos \\
\hline Esgotos vegetação & $\begin{array}{l}\text { (1)Alta } \\
\text { degradação }\end{array}$ & (2)Baixa degradação & (3) Preservada \\
\hline Uso por animais & (1) Presença & (2) Apenas Marcas & (3) Não detectada \\
\hline Uso por humanos & (1) Presença & (2) Apenas Marcas & (3) Não detectada \\
\hline Proteção do local & (1)Sem proteção & $\begin{array}{l}\text { (2) Com proteção, mas } \\
\text { com acesso }\end{array}$ & $\begin{array}{l}\text { (3) Com proteção, mas } \\
\text { sem acesso }\end{array}$ \\
\hline $\begin{array}{l}\text { Proximidade de residências ou } \\
\text { estabelecimentos }\end{array}$ & $\begin{array}{l}\text { (1) Menos de } 50 \\
\text { metros }\end{array}$ & $\begin{array}{l}\text { (2) Entre } 50 \text { e } 100 \\
\text { metros }\end{array}$ & (3) Mais de 100 metros \\
\hline Tipo de área de inserção & (1) Ausente & $\begin{array}{ll}\text { (2) } & \text { Propriedade } \\
\text { Privada } & \end{array}$ & $\begin{array}{l}\text { (3) Parques ou áreas } \\
\text { protegidas }\end{array}$ \\
\hline
\end{tabular}

Fonte: Gomes et al., (2005)

O Índice de degradação nos pontos é determinado pela somatória dos pontos com propósito determinar a classificação quanto o grau de preservação conforma estão apresentados a seguir, Tabela 2: 


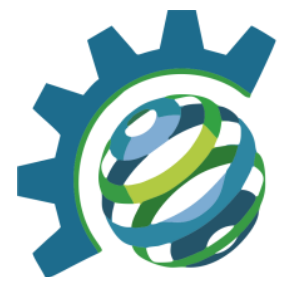

Tabela 2. Classificação dos pontos quanto ao grau de preservação.

\begin{tabular}{l|l|l}
\hline Classe & Grau de Preservação & Pontuação Final* \\
\hline A & Ótima & Entre 37 a 39 pontos \\
B & Boa & Entre 34 a 36 pontos \\
C & Razoável & Entre 31 a 33 pontos \\
D & Ruim & Entre 28 a 30 pontos \\
E & Péssima & Abaixo de 28 pontos \\
\hline
\end{tabular}

(*) Notas para os 13 parâmetros observados (através da somatória dos pontos obtidos na quantificação da analise macroscópica

Fonte: Gomes et al., (2005).

\section{RESULTADOS E DISCUSSÃO}

A análise macroscópica foi realizada em 3 (três) pontos situados na nascente, parte intermediária do curso hídrico e na foz. O ponto 1 , nascente, está localizada na Fazenda de Almecegas denominada Fazenda Brota d'Água distrito de Luiz Pires de Minas na Zona Rural do Município de Coração de Jesus, na nascente surge um córrego chamado Brota d'Água que desagua na barragem da Comunidade Almecegas, que foi construída para o encontro das nascentes da região. No ponto 2 que é a parte intermediária do curso hídrico em estudo, está localizado em outra fazenda denominada Fazenda Almecegas onde passa o fio d'água denominado Córrego Almecegas que segue o percurso para desaguar no Rio Pacuí, ponto 3 que é a foz.

No ponto 1 (um) a nascente situada a lat. $16^{\circ} 27^{\prime} 51.76^{\prime \prime} \mathrm{S}$, e long. $44^{\circ} 17^{\prime}$ 39,24” O, a água apresentou-se transparente, sem odor, sem espumas e sem óleos na superfície. Não foi detectado nenhuma rede de esgoto doméstica, os materiais flutuantes e lixos provém das folhas e galhos caídos das árvores pois a vegetação é preservada com árvores de Pindaíba, Almecegas, Aroeira entre outras. Não foi detectada a presença de animais na nascente nem próximo, já a presença de humanos é constante, pois é retirada água da nascente para consumo. O local é protegido com raio de 15 metros, segundo o Código Florestal Brasileiro e documentos da propriedade é uma área consolidada, pois tem atividades agrossilvipastoris na região da nascente. Esta está localizada em uma propriedade privada onde as residências próximas ultrapassam a 100 metros, segundo moradores que residem próximo a nascente, esta teria vários pontos de surgência no mesmo local, até nos dias atuais se escavar em qualquer ponto próximo mina água, recentemente foi feito um projeto de proteção de nascente feito pela SENAR-MG juntamente com os moradores da região. 

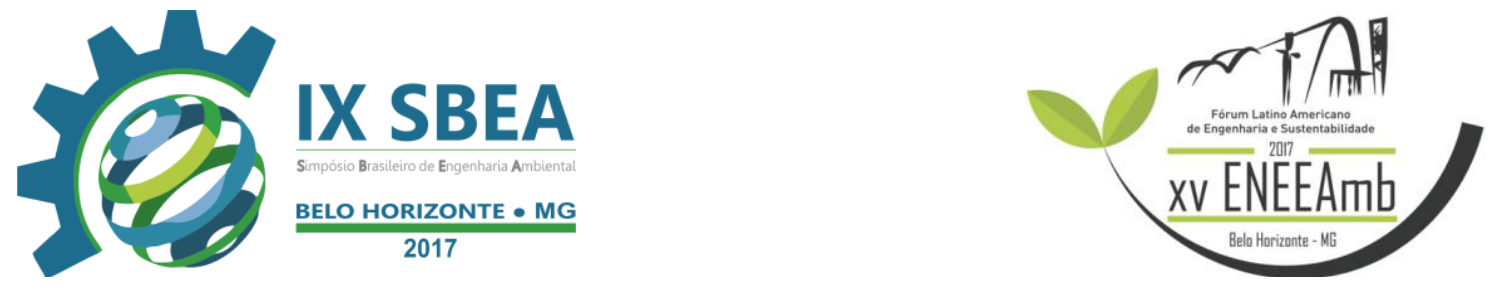

Figura 1. Nascente do Córrego Almecegas, localmente conhecido como Brota d'água.

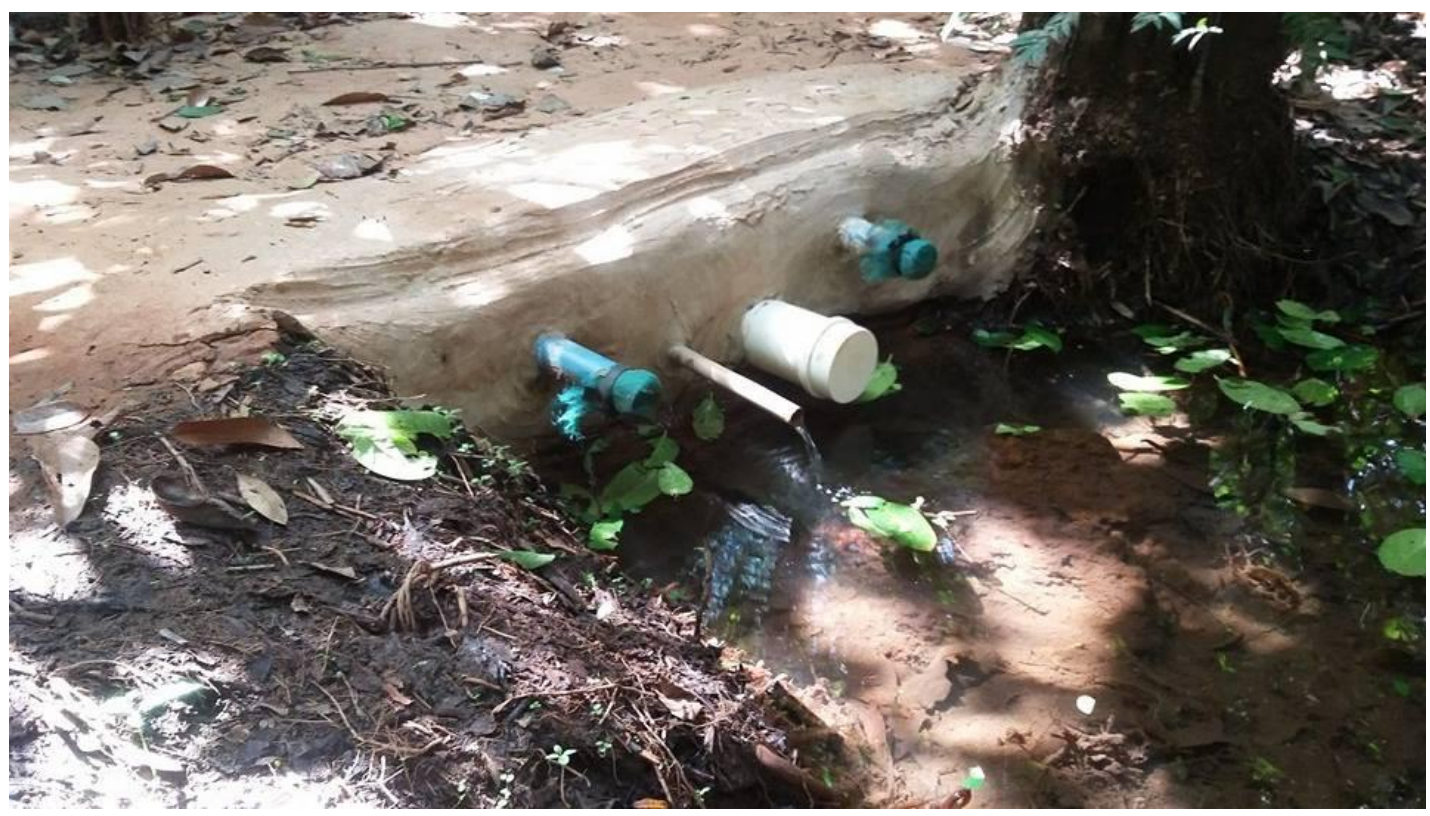

Fonte: Próprio autor.

No ponto 2 a parte intermediária do curso hídrico situada a latitude $16^{\circ} 28^{\prime} 40,6^{\prime \prime}$ $\mathrm{S}$ e longitude $44^{\circ} 18^{\prime} 25.13^{\prime} \mathrm{O}$, a água mostrou-se escura, sem odor, sem espumas e sem óleos no curso hídrico. Não foi detectada nenhuma rede de esgoto doméstica, os materiais flutuantes e lixos provêm das folhas e galhos caídos das árvores, lodos, sacos plásticos e garrafas pet, foi constatado que a vegetação não é preservada somente com algumas árvores de mangue, ingá e gameleira. No entorno da área há presença de animais, e a presença de humanos é constante, uma vez que nesta parte com curso hídrico é usado como acesso a outras propriedades e para dessedentação de animais, visto que o local não é protegido tem uma baixa degradação. Esta está localizada em uma propriedade privada onde as residências próximas entre 50 e 100 metros do curso hídrico. 

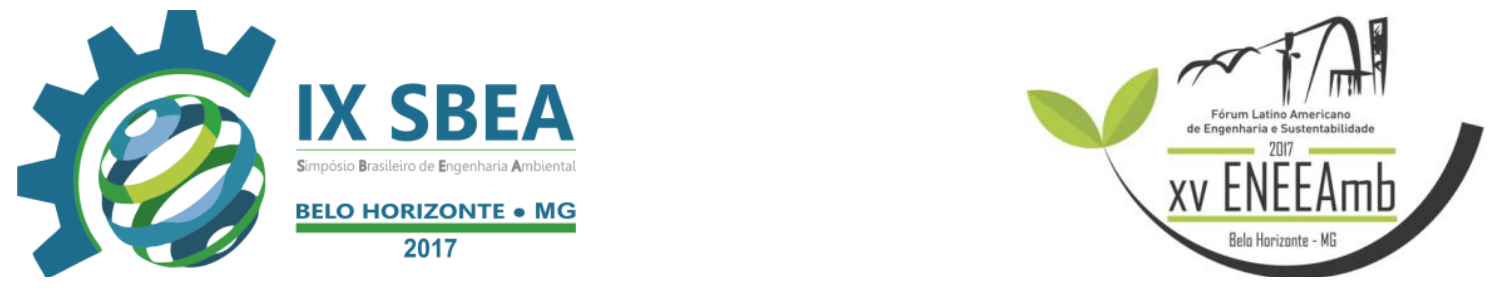

Figura 2. Parte intermediária do curso Córrego Almecegas. Observa-se pegadas de animais na parte esquerda inferior da imagem.

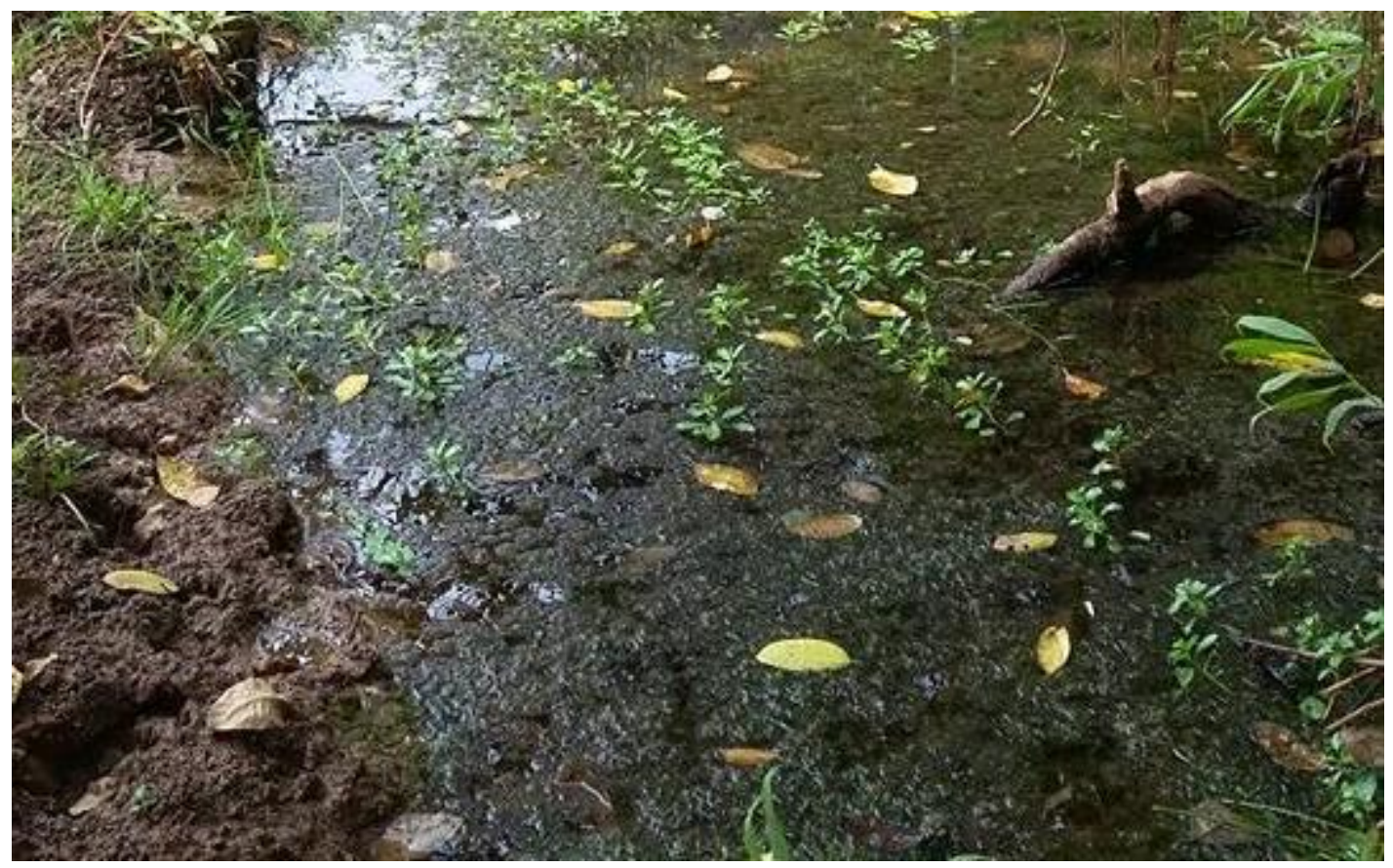

Fonte: Próprio autor.

No ponto 3, na foz situada a latitude $16^{\circ} 28^{\prime} 59.38^{\prime \prime}$ S e longitude $44^{\circ} 19^{\prime} 01.13$ ” O, a água apresentou-se escura, sem odor, sem espumas e sem óleos na foz. Não foi detectada nenhuma rede de esgoto doméstica, os materiais flutuantes e lixos é resultado das folhas e galhos caídos das árvores, sacos plásticos e de agrotóxicos e garrafas pet, foi evidenciado que a vegetação não é preservada somente com algumas árvores de mangue, ingá e gameleira. No entorno da área há presença de animais, e a presença de humanos é frequente, o curso hídrico é usado como acesso a outras propriedades, para dessedentação de animais, irrigação de atividades agrossilvipastoris, visto que o local não é protegido tem alta degradação. Esta está localizada em uma propriedade privada onde as residências próximas entre 50 e 100 metros do curso hídrico. 


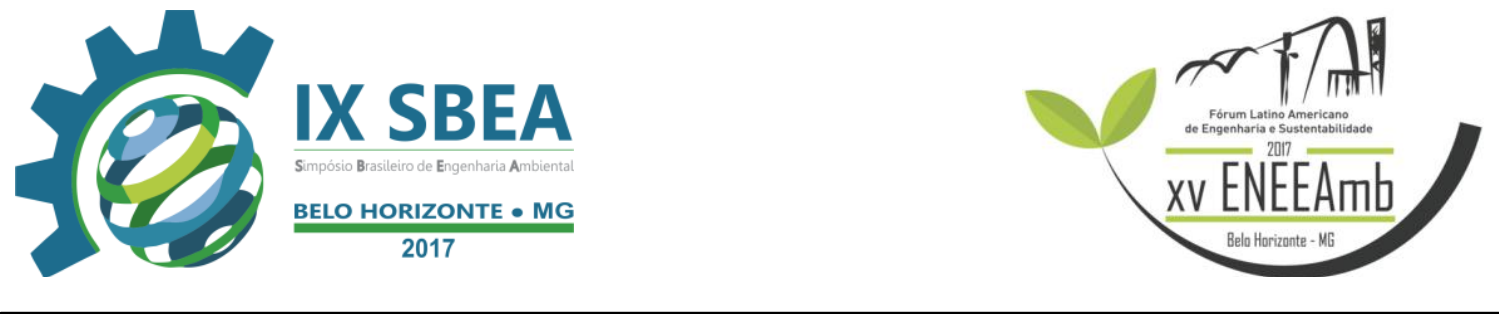

Figura 3. Foz do Córrego Almecegas, ao encontro do Rio Pacuí.

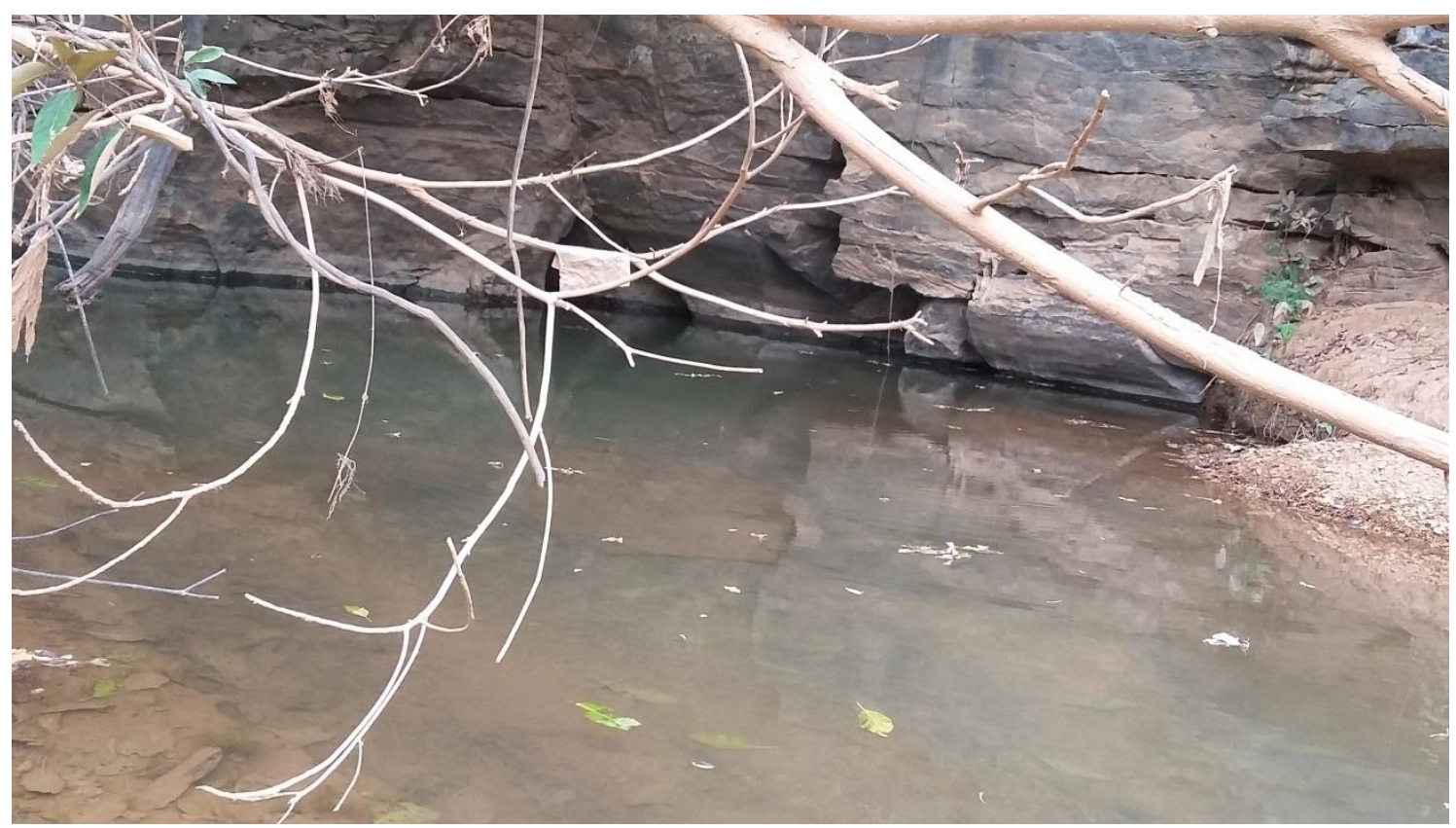

Fonte: Próprio autor.

Os resultados dessas análises apresentam-se resumidas na tabela 1 e 2, que segue.

Tabela 3. Quantificação das análises dos parâmetros macroscópicos.

\begin{tabular}{|c|c|c|c|}
\hline & $\begin{array}{l}\text { Ponto } 1 \\
\text { Nascente }\end{array}$ & $\begin{array}{c}\text { Ponto } 2 \\
\text { Meio do curso hídrico }\end{array}$ & $\begin{array}{l}\text { Ponto } 3 \\
\text { Foz }\end{array}$ \\
\hline Cor da água & 3 & 1 & 1 \\
\hline Odor & 3 & 3 & 3 \\
\hline Lixo ao redor & 3 & 2 & 2 \\
\hline Matérias Flutuantes & 2 & 1 & 2 \\
\hline Espumas & 3 & 3 & 3 \\
\hline Óleos & 3 & 3 & 3 \\
\hline Esgoto & 3 & 3 & 3 \\
\hline Vegetação & 3 & 2 & 1 \\
\hline Uso por animais & 3 & 1 & 1 \\
\hline Uso por humanos & 1 & 1 & 1 \\
\hline Proteção & 3 & 1 & 1 \\
\hline $\begin{array}{l}\text { Proximidade com } \\
\text { residências }\end{array}$ & 3 & 2 & 2 \\
\hline Tipo de áreas de inserção & 2 & 2 & 2 \\
\hline TOTAL & 35 & 25 & 25 \\
\hline Classificação & B (Boa) & E (Péssima) & E (Péssima) \\
\hline
\end{tabular}


Os resultados obtidos possibilitaram o desenvolvimento de propostas para promover um processo de melhoria contínua na preservação do afluente observado, assim constatando a necessidade de promover a conscientização de recuperar e preservar, não só o córrego estudado, mas como todos os outros, por se fazer a cada dia mais necessário e escasso a disponibilidade da água em condições apropriadas para o consumo humano nas mais diferentes atividades desempenhadas.

\section{CONCLUSÕES/RECOMENDAÇÕES}

Através do presente trabalho, percebemos na prática a importância de se ter um acompanhamento e controle dos corpos hídricos para que seja melhorada as suas condições de preservação e recuperação, caso for necessário. Quanto ao afluente estudado, em seu primeiro ponto de amostra, onde está situada a sua nascente, do córrego Brota d'água, apresentam boas condições de preservação, porém existe intervenções antrópicas. No segundo ponto o cenário muda, tendo a coloração da água alterada, presença de lixo e supressão da mata ciliar. No ultimo ponto de observância o quadro de degradação se repete, porém de uma maneira mais severa sendo encontrada embalagem de defensivos agrícolas.

Portanto, em condições gerais, no decorrer do córrego foi constatado a necessidade de recuperar a mata ciliar e isolar para que não aja contato com rebanho e que seja controlado intervenção antrópica.

\section{REFERÊNCIAS BIBLIOGRÁFICAS}

Botelho, C.G; Campos, C.M.; Valle, R.H.P.; Silveira, I.A. 2001. Recursos naturais renováveis e impacto ambiental: água. Editora Universidade Federal de Lavras, Lavras. 187.

Fontes, L.E.F.; Ribeiro, G.A.; Fernandes, R.B.A. 2003. Ação ambiental: impactos ambientais. Editora Universidade Federal de Viçosa, Viçosa. 34.

Gomes, P. M: Melo, C. DE; Avaliação dos impactos ambientais em nascentes na cidade de Uberlândia-MG: análise macroscópica. In <www.seer.ufu.br/index.php/sociedadenatureza/article/view/9169 > Acesso em: $28 \mathrm{de}$ maio de 2016.

TUCCI, C. E. M. Modelos Hidrológicos. Porto Alegre: Ed. da Universidade/UFRGS/ABRH, 1998. 669p. 